\title{
Mutsu's last chance
}

\section{Tokyo}

JAPAN's one and only nuclear powered ship, the infamous Mutsu, has sprung to life after sitting rusting in port for 16 years. The ship, which has gobbled up hundreds of millions of dollars in public funds, will be given one last chance to prove itself before being mothballed next year. The saga of the Mutsu draws attention to the lack of a central organization to coordinate and monitor the activities of the various science-related ministries and agencies in Japan.

Mutsu was launched in 1968 and was ready for sea trials by 1972 . But local fishermen, fearing radioactive pollution from the ship, prevented Mutsu from putting to sea from Mutsu City port in northern Japan for two years. When the ship finally set sail, disaster struck almost immediately. The reactor began to leak and the crew had to stuff rice and socks into it to try and stem the flow of radiation as the ship headed back to home port where local fishermen barred re-entry until suitable compensation was paid and the government agreed to dock the ship elsewhere (see Nature 310, 531; 1984).

Mutsu then wandered from port to port (never under its own power) in search of a home. Fourteen years later the ship eventually found its way back to Mutsu City where it has been anchored at a custombuilt new port for the past two years.

Last week, the reactor was started up and reached criticality. The Science and Technology Agency (STA), which is responsible for the ship, had planned to start up the reactor last year but some of the SOUTH AFRICAN UNIVERSITIES -

\section{Appointments still under tight control}

\section{Cape Town}

THE South African government last week refused to grant a work permit to the vicerector-designate of the University of the Western Cape (UWC), Professor Njabulo Ndebele. Professor Ndebele, 42, is the national president of the Congress of South African Writers, and at present holds the position of deputy vice-chancellor of the National University of Lesotho. $\mathrm{He}$ is a citizen of that country.

Reacting to the announcement, the rector of UWC, Professor Jakes Gerwel, said: "Professor Ndebele is one of the most highly esteemed intellectuals in southern Africa, and we were really not anticipating that in the present climate a person of his stature would be refused a work permit". Gerwel has asked for an urgent meeting with the Minister of Home Affairs, Gene Louw. fuel rods and control rods were found to be rusty after being idle for 16 years and had to be replaced.

If all goes well with the test runs, Mutsu will set sail in about five months on a final year-long cruise to the South Pacific (provided fishermen and anti-nuclear activists do not intervene). But some experts have expressed fears that extra concrete and zirconium shielding that have been added around the reactor may have made the ship top heavy and unstable in rough weather. It also seems unlikely that much will be learned from the tests. Western nations gave up the idea of commercial nuclear-powered ships decades ago. And Japan has no plans to follow up Mutsu. The main argument that STA officials offer for carrying out the tests is that they have to collect data to justify spending $¥ 117,000$ million ( $\$ 740$ million) over the past three decades.

Such an attitude illustrates a major defect in the Japanese government's management of science and technology projects. Once big projects get under way, there is no mechanism or central organization (such as the Office of Technology Assessment in the United States, for example) to re-appraise them or change direction. And government ministries and agencies determined to maintain their own territory and budgets will keep pumping money into projects no matter how absurd and out of touch they may be.

The final fate of Mutsu is unknown. It may be made into a museum; another possibility is that it will be converted to diesel power.

David Swinbanks INTERNATIONAL ORGANIZATIONS -

\section{United States says 'No' to UNESCO}

\section{Washington}

DESPITE increasing pressure from scientists for the United States to rejoin the United Nations Educational, Scientific and Cultural Organization (UNESCO), the State Department last week said that it would not do so until the organization is better managed and politically unbiased. Recent reforms by UNESCO directorgeneral Federico Mayor have caused internal strife in the organization, and his appointment of a Soviet citizen to direct communications and information has been opposed (see Nature 344, 368; 29 March 1990). "Very little has changed since the United States withdrew at the end of 1984", said State Department spokeswoman Margaret Tutwiler. She said that a full explanation for the decision will be submitted to Congress on 17 April.

G. Christopher Anderson
No news is bad news for appointments to advisory board

\section{London}

The UK Department of Education and Science (DES) is finding the appointment of independent members to the reconstituted Advisory Board for the Research Councils (ABRC) more time-consuming than expected.

When Secretary of State John MacGregor announced on 19 January that the ABRC would be given a more explicit remit to improve coordination between the research councils, with its membership cut from 26 to 14 (see Nature 343, 294; 1990), he hoped that the board's full membership would be announced "within a few weeks".

The new arrangements were to take effect from 1 April, but as Nature went to press, Peter Thorpe, secretary to the ABRC, was still waiting for an announcement from the DES. "We have been pressing for the appointments to be made quickly", he says, and adds that he "didn't assume we would be into April" before the final shape of the board was made certain. The reasons for the delay are unclear, but a spokesman for the DES says that an announcement is likely to be made "very soon".

The new ABRC will be chaired, as before, by Sir David Phillips, of the University of Oxford, and will comprise the five heads of the UK research councils, two assessors (a representative from the DES and the Chief Scientific Adviser from the Cabinet Office) and six independent members. Time will tell if the new-format ABRC can improve coordination between the research councils, a matter that MacGregor has asserted demands "urgent attention".

The most pressing concerns are the conflicting claims for primacy in biotechnological research made by the Science and Engineering Research Council and the Medical Research Council, and for better coordination between the land-based environmental research programmes of the Agricultural and Food Research Council and the Natural Environment Research Council.

One worry is that in remaining merely as an advisory body to the DES, the ABRC will lack the power to take its proposed "interventionist" role in disputes between research councils (see Nature 343, 293; 1990). Two members of the old ABRC, both government department chief scientists, argued that the new body should be given stronger executive powers, but were defeated by a majority ABRC decision. The first meeting of the new ABRC is planned for 20 April, but Thorpe says that the DES should move quickly if the independent members of the board are all to attend.

Peter Aldhous 